\title{
Analisis Perencanaan Sumber Daya Manusia (SDM) Dalam Peningkatan Mutu Pendidikan Di SMA Muhammadiyah Selong
}

\author{
Masbullah $^{1}$, Salmi Yuniar Bahri2 ${ }^{*}$ \\ ${ }^{1,2}$ Administrasi Publik, STIA Muhammadiyah Selong, Selong, Indonesia \\ Email: ${ }^{1}$ masbullah88@gmail.com, ${ }^{2}$ salmijuniar@gmail.com
}

\begin{abstract}
Human resources $(H R)$ is the most important asset in an organization/company, especially in an educational institution, so it is very important that existing human resources can be planned as well as possible, in order to realize the goals of the organization/institution. There are many models of effective and efficient human resource planning, but effective and efficient human resource planning is not realized optimally, only imagination. Therefore, this study was conducted with the aim of analyzing human resource planning and finding solutions to problems that affect human resource planning at SMA Muhammadiyah Selong. This research is a qualitative descriptive research in the field. Technically data collection is done by interview, observation, and document study. After the data is collected, then classify, design and present the data according to their respective data types. Before the data is collected first and checked for validity. The results of this study indicate that human resource planning is carried out through programs, planning stages, including indicators or quality targets to be achieved as a process of improving education. The form of planning includes the arrangement of resources which includes the development of human resources, the development of the learning process, as well as increasing the capacity of human resources to improve the quality of education.
\end{abstract}

Keywords: Management, Planning, Human Resources, SMA Muhammadiyah Selong

\begin{abstract}
Abstrak
Sumber daya manusia (SDM) merupakan aset terpenting dalam suatu organisasi/perusahaan khususnya dalam suatu lembaga pendidikan, sehingga sangat penting agar sumber daya manusia yang ada dapat direncanakan dengan sebaik-baiknya, guna mewujudkan tujuan organisasi/lembaga tersebut. Ada banyak model manajemen perencanaan sumber daya manusia yang efektif dan efisien, namun perencanaan sumber daya manusia yang efektif dan efisien terkadang tidak terwujud secara maksimal, hanya imajinasi semata. Oleh karena itu, penelitian ini dilakukan dengan tujuan untuk menganalisis perencanaan sumber daya manusia dan mencari solusi atas permasalahan yang mempengaruhi perencanaan sumber daya manusia di SMA Muhammadiyah Selong. Penelitian ini merupakan penelitian deskriptif kualitatif lapangan. Secara teknis pengumpulan data dilakukan dengan wawancara, observasi, dan studi dokumen. Setelah data terkumpul, kemudian mengklasifikasikan, merancang dan menyajikan data sesuai dengan jenis datanya masing-masing. Sebelum data dikumpulkan terlebih dahulu dan diperiksa keabsahannya. Hasil penelitian ini menunjukkan bahwa perencanaan sumber daya manusia dilakukan melalui program, langkah perencanaan, tahapan perencanaan, termasuk indikator atau target mutu yang ingin dicapai sebagai proses peningkatan
\end{abstract}


pendidikan. Bentuk perencanaan meliputi penataan sumber daya yang memuat pengembangan sumber daya manusia, pengembangan proses pembelajaran, serta peningkatan kapasitas sumber daya manusia untuk meningkatkan mutu pendidikan.

Kata Kunci: Manajemen, Perencanaan, Sumber Daya Manusia, SMA Muhammadiyah Selong

\section{PENDAHULUAN}

Pada dasarnya peningkatan mutu pendidikan telah lama dilakukan oleh para pelaku pembangunan di bidang pendidikan Indonesia, namun kenyataan dan bukti empiris yang kita lihat di lapangan menunjukkan bahwa mutu pendidikan di Indonesia masih dikatakan rendah. Oleh karena itu, dapat dikatakan bahwa sampai saat ini penekanan pendidikan masih pada upaya peningkatan mutu. Konsekuensi logis dari upaya peningkatan mutu pendidikan adalah perlunya peningkatan mutu seluruh komponen sistem pendidikan, baik berupa sumber daya manusia maupun sumber daya materiil.

Dalam upaya peningkatan mutu, komponen pendidikan berupa sumber daya manusia (SDM) memiliki peranan yang sangat penting dalam tujuan pendidikan yang diinginkan. Oleh karena itu, lembaga pendidikan perlu memberikan perhatian yang serius terhadap sumber daya manusia yang terlibat, tidak hanya guru, kepala sekolah, komite sekolah, pengawas sekolah dan karyawan tetapi juga siswa, wali siswa dan masyarakat. Karena hanya kesiapan sumber daya manusia yang akan mampu membawa lembaga pendidikan eksis dan dapat meningkatkan mutu pendidikan. Pada dasarnya Sumber Daya Manusia menyadari pengaruh yang sangat besar dan dianggap sebagai kunci utama dalam peningkatan mutu pendidikan. Hal ini dapat dipahami dari kenyataan bahwa secara keseluruhan sumber daya yang terdapat dalam suatu organisasi, Sumber Daya Manusia adalah satu-satunya sumber daya yang memiliki akal, perasaan keinginan, bakat, keahlian, serta selera dan inisiatif. Potensi Sumber Daya Manusia juga berpengaruh dalam pencapaian tujuan visi dan misi organisasi, karena semakin maju dan canggihnya teknologi, perkembangan informasi, tersedianya sarana dan prasarana yang memadai, namun tanpa Sumber Daya Manusia yang handal, tujuan organisasi akan menjadi sulit untuk dicapai. Dengan kata lain, komponen pendidikan berupa Material Resources tidak dapat berjalan efektif tanpa adanya komponen berupa Sumber Daya Manusia.

Keberlanjutan suatu organisasi tidak lepas dari peran sumber daya manusia untuk mengelola semua kegiatan yang telah direncanakan dengan baik. Setiap organisasi yang nama dan jenisnya selalu memerlukan perencanaan yang matang dalam mencapai tujuan organisasi. Suatu organisasi akan berjalan dengan baik jika dikelola dengan baik pula, hal ini dikarenakan manajemen dan organisasi merupakan satu kesatuan yang saling melengkapi. Sebagaimana dikemukakan oleh Hasibuan bahwa dalam suatu organisasi atau perusahaan, organisasi adalah suatu alat atau tempat untuk mengatur manusia, uang, metode, bahan, mesin, dan pasar serta segala kegiatan proses manajemen dalam mencapai tujuan. Tegasnya, itu hanya bisa dilakukan di dalam suatu organisasi (wadah/tempat). Karena disinilah tempat kerjasama, proses manajemen, pembagian kerja, koordinasi, dan integrasi dilakukan untuk mencapai tujuan yang ingin dicapai (Hasibuan, 2001). Kedudukan manajemen sumber daya manusia menjadi sangat penting dan utama karena keberhasilan pengelolaan sumber daya manusia yaitu sekolah dan guru sehingga output yang dihasilkan memiliki standar mutu pendidikan. Keberadaan guru sebagai pelaksana program pertama dan utama di sekolah diharapkan dapat dimanfaatkan secara maksimal, sehingga dapat meningkatkan mutu pendidikan di 
sekolah. Namun kenyataan di SMA Muhammadiyah Selong keberadaan guru belum optimal dan efektif dalam meningkatkan mutu pendidikan, karena pada jenjang pendidikan dalam hal ini penempatan tenaga pendidik dan tenaga kependidikan belum sesuai dengan fungsinya. profesi. Dalam meningkatkan mutu pendidikan, diperlukan pendidik dan tenaga kependidikan yang profesional dan mampu mencapai tujuan pendidikan. Dan peningkatan mutu pendidikan di SMA Muhammadiyah Selong belum efisien karena disiplin pendidik dan tenaga kependidikan masih kurang sehingga tujuan pendidikan tidak sesuai dengan perencanaan SDM yang telah disusun. Pada akhirnya guru tidak menyentuh proses manajemen untuk peningkatan mutu pendidikan secara keseluruhan dan tidak sesuai dengan peran dan fungsinya membantu kepala sekolah dalam pengelolaan peningkatan mutu pendidikan (Dedi, 2001). Organisasi yang tidak didukung oleh pegawai/karyawan yang sesuai dengan kuantitas, kualitas, strategi dan operasional yang baik, dapat dipastikan organisasi akan kesulitan untuk mempertahankan dan mengembangkan eksistensinya di masa yang akan datang (Riva'i, 2004). Organisasi dalam perjalanan waktu memiliki sejumlah tujuan yang ingin dicapai dalam kurun waktu tertentu. Organisasi umumnya menganut prinsip/pola jangka pendek, jangka menengah dan jangka panjang atau lebih. Untuk mewujudkan tujuan tersebut, biasanya telah disusun strategi dan rencana operasional sebagai pedoman tujuan dari rencana tersebut. Satu hal yang tidak boleh diabaikan dalam praktik organisasi adalah pentingnya integrasi atau integrasi antara perencanaan bisnis dan perencanaan SDM. Perencanaan bisnis diikuti dengan perencanaan SDM untuk meningkatkan efektifitas dan efisiensi kerja organisasi. Sebaliknya, perencanaan bisnis yang tidak dibarengi dan diikuti dengan perencanaan SDM yang baik akan mempengaruhi organisasi. Tidak sedikit perusahaan besar dalam praktik organisasi bisnis yang kurang memperhatikan atau porsi keterlibatan pengelola SDM dalam membuat rencana bisnis yang akan dijalankan dalam kurun waktu tertentu. Biasanya pada level ini seorang pemimpin perusahaan melibatkan manajer pemasaran dan manajer keuangan, sehingga perusahaan tidak memiliki sumber daya manusia yang sesuai dengan kebutuhan organisasi. Melalui perencanaan SDM, perencanaan SDM, baik secara kuantitas maupun kualitas, dapat dipersiapkan dan dikembangkan sejak dini sehingga dapat mencegah terjadinya permasalahan kelebihan pegawai atau ketidaksesuaian kompetensi antara pegawai yang ada dengan kompetensi yang dibutuhkan oleh pekerjaan/organisasi.

Perencanaan SDM menurut Sherman dan Bohlander sebagaimana dikutip oleh Hadari Nawawi adalah mengantisipasi proses dan persyaratan untuk mengatur arus pergerakan tenaga kerja ke dalam (promosi, transfer, dan demosi) dan (pensiun, pensiun, dan) pemutusan hubungan kerja) dalam suatu organisasi atau perusahaan ( Nawawi, 2003). 2015). Definisi ini menjelaskan pentingnya perencanaan SDM, karena migrasi SDM harus diprediksi sejak awal. Sekolah sebagai organisasi tempat berkumpulnya sekelompok orang, masing-masing secara individu atau kelompok, saling bekerjasama untuk mencapai tujuan. Karena lembaga pendidikan formal tidak akan mampu mempertahankan eksistensinya, mengembangkan dan memajukan lembaganya di masa depan jika berjalan secara mandiri (Ritawati, 2015). Oleh karena itu, perlu dilakukan langkah-langkah untuk lebih menjamin ketersediaan guru/dosen yang tepat untuk pekerjaan yang sesuai dengan kebutuhan. Perencanaan sumber daya manusia merupakan proses dalam menentukan pergerakan guru/dosen dalam lembaga/instansi/institusi dari posisi yang diinginkan di masa depan, sedangkan sumber daya manusia adalah seperangkat proses-proses dan aktivitas yang dilakukan bersama oleh pimpinan tertinggi dari sumber daya manusia dan para staf pendidik untuk memecahkan masalah lembaga/lembaga/instansi yang terkait dengan guru/dosen 
(Ritawati, 2015). Dalam pembahasan ini, manajemen personal adalah dalam pengelolaan staf/karyawan guru dan non-guru. SMA Muhammadiyah Selong yang berlokasi di Jln. TGH. Omar No. 22 Selong, adalah salah satu SMA di bawah naungan Perhimpunan Muhammadiyah, Lombok Timur, Nusa Tenggara Barat. SMA Muhammadiyah Selong merupakan sekolah yang memiliki sumber daya manusia yang banyak dan ditempatkan di berbagai posisi. SMA Muhammadiyah Selong Setiap SDM yang bekerja di SMA Muhammadiyah Selong harus berada pada posisi dan menjalankan tugas dan kewajibannya sebagaimana mestinya. Sebagai organisasi yang menjunjung tinggi nilai-nilai keislaman dan muhammadiyah, maka penting bagi SMA Muhammadiyah Selong untuk melakukan perencanaan SDM yang baik, mengingat visi dan misi yang sangat sulit dicapai oleh SMA Muhammadiyah Selong diperlukan SDM yang berkualitas dan tepat sasaran dalam menjalankannya. . Perencanaan SDM sebagai kegiatan yang direncanakan untuk memperkirakan permintaan (demand) sumber daya manusia yang dibutuhkan dalam rangka mewujudkan kegiatan atau operasi yang terkandung dalam strategi dan rencana operasional dalam suatu organisasi, tujuan sederhananya adalah tujuan umum dari perencanaan SDM, implementasinya tidak sesederhana perumusannya. pendidikan dan tenaga kependidikan adalah kriteria pendidikan prajabatan dan kebugaran jasmani dan rohani, serta pendidikan dalam jabatan. SMA Muhammadiyah Selong juga memiliki permasalahan yang sering terjadi, seperti fenomena keluar masuknya guru dan pegawai. Hal ini sangat dimungkinkan karena guru dan pegawai di sekolah swasta sebagian besar adalah guru honorer. Dari permasalahan tersebut, penulis tertarik untuk meneliti bagaimana SMA Muhammadiyah Selong menyikapi permasalahan tersebut dan bentuk perencanaan SDM di SMA Muhammadiyah Selong sehingga dapat menjadi salah satu SMA swasta yang maju dan diperhitungkan di Lombok Timur. Karena organisasi dapat terus berdiri dan berkembang apabila didukung oleh sumber daya manusia yang berkualitas, dalam hal ini tentunya diperlukan perencanaan SDM untuk mengoptimalkan sumber daya manusia yang ada.

\section{KAJIAN TEORI}

\section{a. Meningkatkan Kualitas Pendidikan}

Pengertian mutu meliputi input, proses dan output pendidikan. Sertakan sisa sumber daya seperti peralatan, bahan, uang, dan sebagainya. Sedangkan perangkat lunak input yang dimaksud dalam penelitian ini meliputi struktur organisasi, peraturan perundangundangan, rencana, program dan sebagainya. Oleh karena itu, rendahnya kualitas suatu input dapat diukur dari tingkat kesiapan input tersebut. Semakin tinggi persiapan input, semakin tinggi input institusional yang tersedia. Proses pendidikan adalah mengubah sesuatu menjadi sesuatu yang lain. sesuatu yang mempengaruhi dalam suatu proses, hasil dari proses tersebut disebut juga hasil atau keluaran. Pada pendidikan tinggi mikro (sekolah atau madrasah) proses yang dimaksud adalah proses pengambilan keputusan, proses pengelolaan suatu lembaga, proses pengelolaan program, proses belajar mengajar, proses monitoring dan evaluasi dengan catatan bahwa proses pembelajaran memiliki tingkat kepentingan tertinggi dibandingkan dengan proses lainnya. lainnya sedang berlangsung. Suatu proses akan dikatakan berkualitas tinggi jika mengajarkan dan menyelaraskan serta membimbing masukan sekolah antara guru lain, siswa, kurikulum dan faktor pendukung lainnya secara harmonis sehingga menciptakan situasi belajar yang menyenangkan, mampu mendorong dan memotivasi minat. dan benarbenar mampu memberdayakan siswa. siswa. Keluaran pendidikan adalah kinerja kepala sekolah. Prestasi sekolah adalah prestasi sekolah yang dihasilkan dari proses atau 
perilaku sekolah. Kinerja sekolah dapat diukur dari kualitas, efektivitas, produktivitas, efisiensi, inovasi, kualitas kerja dan semangat kerja selama proses di lembaga pendidikan. Secara khusus terkait dengan output, dapat dijelaskan bahwa output dapat dikatakan bermutu tinggi jika prestasi sekolah, terutama prestasi belajar dalam prestasi akademik oleh siswa berupa nilai, karya ilmiah dan akademik, dan prestasi nonakademik. seperti kebahagiaan dan ketakwaan, kejujuran, sopan santun, olahraga, seni, keterampilan dan kegiatan ekstrakurikuler lainnya (Irchard, 1997). Artinya, manajemen peningkatan mutu dalam dunia pendidikan dapat disebut dengan mengutamakan siswa atau program perbaikan sekolah, yang dapat dilakukan secara kreatif dan konstruktif. Penekanan yang paling penting adalah bahwa peningkatan kualitas dalam program dapat mengubah budaya sekolah. Siswa dan orang tua dapat lebih tertarik dengan perubahan yang dibawa oleh manajemen mutu terpadu melalui berbagai program peningkatan mutu. Pendidikan merupakan pelayanan yang membutuhkan standarisasi mutu. Dalam Peraturan Pemerintah Nomor 19 Tahun 2005, standar pendidikan dapat dimulai dari standar nasional pendidikan yang telah menetapkan kriteria minimal tentang sistem pendidikan nasional di Indonesia meliputi standar kompetensi kelulusan, standar pendidik dan tenaga kependidikan, standar proses, standar sarana dan prasarana, pembiayaan standar, standar manajemen. dan standar penilaian. Standar nasional pendidikan menjadi dasar perencanaan dan pengawasan dalam rangka mewujudkan pendidikan nasional yang berkualitas. Standar nasional pendidikan bertujuan untuk menjamin mutu pendidikan nasional dalam rangka mencerdaskan kehidupan bangsa dan membentuk watak serta peradaban bangsa. Peningkatan mutu pendidikan menjadi sangat penting karena peran sekolah sebagai aktor dasar utama, peran orang tua dan masyarakat dalam meningkatkan suatu hasil pendidikan. Sekolah perlu diberi kepercayaan dan dukungan untuk mengatur dan mengurus diri sendiri sesuai dengan kondisi lingkungan dan kebutuhan masyarakat. Sekolah sebagai lembaga atau lembaga yang mempunyai kesempatan untuk mengelola proses pengelolaan lembaga untuk mencapai tujuan pendidikan (Soebagio, 2000). Konsep pemikiran ini telah mendorong suatu pendekatan baru, yaitu manajemen peningkatan mutu berbasis sekolah, suatu pendekatan yang dikenal dengan manajemen peningkatan mutu sekolah (Suryosubroto, 2004). Setiap lembaga pendidikan ingin mencapai kualitas pendidikan yang tinggi. Tercapainya kualitas-kualitas tersebut menunjukkan bahwa lembaga pendidikan telah berhasil memanfaatkannya sebagai lembaga dan organisasi di tengah-tengah masyarakat. Pendidikan yang bermutu adalah upaya pendidikan yang telah menetapkan standarisasi sistem pendidikan berdasarkan penilaian mutu. Kualitas pendidikan dalam output pendidikan dan proses yang mengarahkan input pendidikan. Ada tiga faktor untuk meningkatkan kualitas pendidikan, antara lain: sumber daya pendidikan dari segi kualitas tenaga kependidikan, biaya, fasilitas pembelajaran, proses pembelajaran yang mendorong siswa untuk belajar secara efektif, dan kualitas output berupa pengetahuan, sikap. , keterampilan dan nilai (Nanang, 2004).

\section{b. Perencanaan Sumber Daya Manusia}

Perencanaan sumber daya manusia atau manpower planning didefinisikan sebagai proses penentuan kebutuhan tenaga kerja dan bagaimana memenuhi kebutuhan tersebut untuk melaksanakan rencana terpadu organisasi (Hasibuan, 2007). Menurut Thomas, perencanaan sumber daya manusia adalah proses memprediksi kebutuhan sumber daya manusia suatu organisasi untuk masa depan sehingga dapat diambil langkah-langkah untuk memastikan bahwa kebutuhan tersebut dapat terpenuhi (Hasibuan, 2007). Sedangkan menurut John B. Miner dan Marry Green Miner dalam bukunya 
Personneland Industrial Relations, perencanaan sumber daya manusia dapat digambarkan sebagai suatu proses yang berusaha untuk memastikan bahwa jumlah dan jenis karyawan yang tepat akan tersedia di tempat yang tepat di tempat yang tepat. waktu untuk masa depan, dan juga masa depan. hal-hal yang diperlukan agar organisasi dapat terus mencapai tujuannya (Hasibuan, 2007: 249). Menurut G. Steiner dikutip dari Nawawi, perencanaan SDM adalah serangkaian kegiatan untuk meramalkan (memprediksi atau memperkirakan) permintaan atau permintaan kera di masa depan dalam suatu organisasi/perusahaan, yang meliputi pemanfaatan sumber daya manusia yang ada dan pengadaan tenaga kerja. bahwa perencanaan SDM adalah proses pengambilan keputusan prediktif, yang hasilnya selalu mungkin salah. Oleh karena itu, perlu digunakan dan dikembangkan metode dan/atau teknik prediksi yang secara ilmiah memiliki tingkat akurasi yang tinggi dan tingkat kesalahan atau tuntutan SDM yang tinggi agar kedepannya dapat melaksanakan perencanaan bisnis sebagai organisasi/perusahaan secara efektif dan efisien. efisien. Untuk itu, prediksi jumlah SDM yang dibutuhkan tidak boleh berlebihan, karena akan berdampak pada pemborosan, terutama dalam penyediaan pembiayaan (cost) SDM. yang sebenarnya tidak dibutuhkan. Di sisi lain, prediksi tidak boleh terlalu kurang dari sumber daya manusia yang dibutuhkan, karena akan berdampak pada beban kerja masing-masing sumber daya manusia yang terlalu berat dan pekerjaan sulit berlangsung secara efektif dan efisien. Selain itu juga tidak boleh ada jebakan jabatan/pekerjaan yang dapat mengakibatkan terlupanya pekerjaan/jabatan dan dapat mengurangi keberhasilan atau bahkan menyebabkan kegagalan organisasi/perusahaan. Untuk itu diperlukan kegiatan Audit SDM atau kegiatan Analisis Tenaga Kerja (Manpower Analysis) untuk memaksimalkan penggunaan sumber daya manusia yang dimiliki. Pada bagian ini cukup dinyatakan bahwa Audit SDM dilaksanakan untuk mengimplementasikan prinsip utama dalam Perencanaan SDM bahwa (Nawawi, 2015) Perencanaan SDM harus dimulai dari pendayagunaan SDM yang sudah dimiliki secara efektif dan efisien (optimal) dan hanya akan menambah atau merekrut sumber daya manusia dari luar apabila ternyata terjadi kekurangan sumber daya manusia untuk melaksanakan tugas pokok organisasi/perusahaan. Perencanaan SDM adalah proses penetapan strategi untuk memperoleh, memanfaatkan, mengembangkan, dan memelihara SDM sesuai dengan kebutuhan organisasi/perusahaan saat ini dan perkembangannya di masa yang akan datang (Nawawi, 2015). Pengertian ini sifatnya lebih luas karena perencanaan SDM tidak diharapkan untuk memperoleh sumber daya manusia yang dibutuhkan oleh suatu organisasi/perusahaan sebagaimana dimaksud dalam definisi-definisi sebelumnya. Pemahaman ini juga tentang bagaimana memanfaatkan, mengembangkan dan memelihara potensi SDM setelah dipekerjakan sebagai hasil dari Perencanaan SDM yang akurat. Kegiatan yang terakhir ini dilakukan pada beberapa kegiatan Manajemen SDM lainnya, seperti pelatihan, penilaian kinerja, pengembangan SDM, dll. Kegiatan ini hanya mungkin dilakukan secara efektif dan efisien jika dari perencanaan SDM ditentukan kualifikasi yang akurat untuk setiap bidang kerja/ posisi kosong yang membutuhkan SDM, baik dari sumber internal (promosi dan pindah) maupun eksternal (Nawawi, 2015). Untuk itu diperlukan strategi perencanaan untuk memperoleh, memelihara dan mengembangkan potensi sumber daya manusia dalam suatu organisasi/perusahaan. Istilah strategi pada awalnya sangat populer dalam penggunaannya di lingkungan militer. Kemudian lambat laun semakin banyak digunakan dalam bidang-bidang lain termasuk perencanaan, karena relatif dianggap mampu mengungkapkan secara tepat proses atau rangkaian kegiatan untuk mencapai tujuan suatu rencana, termasuk perencanaan SDM. Berkaitan dengan hal tersebut, maka strategi dalam perencanaan SDM juga dapat diartikan sebagai cara, teknik/metode atau 
taktik utama yang digunakan untuk memperoleh sumber daya manusia yang memiliki potensi kemampuan yang besar dalam bidang pekerjaan/jabatan tertentu, terutama yang berkaitan dengan bisnis. SDM yang diperoleh dengan strategi yang tepat dalam melaksanakan perencanaan SDM akan dimanfaatkan dan dikembangkan secara optimal dalam menghadapi tantangan perubahan dan perkembangan lingkungan bisnis di masa mendatang (Nawawi, 2015).

Perencanaan sumber daya manusia didefinisikan sebagai langkah-langkah tertentu yang diambil oleh manajemen untuk lebih memastikan bahwa organisasi memiliki tenaga kerja yang tepat yang tersedia untuk menduduki berbagai posisi, posisi dan pekerjaan pada waktu yang tepat. , semua dalam tujuan dan berbagai target yang telah dan akan ditetapkan (Sondang, 2001). Sedangkan pengertian perencanaan sumber daya manusia menurut Henry Simamora adalah mengumpulkan dan menggunakan informasi untuk mendukung keputusan investasi sumber daya dalam berbagai kegiatan sumber daya manusia (Henry: 50). Jadi ini yang dimaksud dengan perencanaan sumber daya manusia mengacu pada pemahaman Sondang P. Siagian adalah langkah-langkah tertentu yang diambil oleh manajemen untuk lebih memastikan bahwa organisasi memiliki lebih banyak tenaga kerja yang tepat untuk menduduki berbagai posisi, posisi dan pekerjaan yang tepat pada waktu yang tepat. . semuanya dalam tujuan dan berbagai sasaran yang telah dan akan ditetapkan (Sondang, 2001). Proses atau langkah-langkah yang diambil untuk kebutuhan sumber daya manusia yang tersedia bagi organisasi dalam rangka menentukan keputusan yang akan datang, untuk mencapai tujuan. Dari uraian di atas, dapat disimpulkan bahwa perencanaan sumber daya adalah proses menganalisis dan menganalisis sumber daya organisasi untuk kebutuhan sumber daya manusia sehingga organisasi dapat menentukan langkah-langkah yang harus diambil untuk mencapai tujuan. Selain itu, pentingnya diadakannya perencanaan sumber daya manusia adalah agar keberadaan organisasi memiliki gambaran masa depan yang jelas, dan mampu mengantisipasi kekurangan kualitas tenaga kerja yang dibutuhkan. Untuk perencanaan SDM yang baik, maka diperlukan tahapan atau langkah dasar yang harus dicapai, yaitu: Mampu mendefinisikan secara jelas kualitas dan kuantitas SDM, mengumpulkan data dan informasi lengkap tentang SDM, mengelompokkan data dan informasi, kemudian menganalisis. itu, menentukan beberapa alternatif. yang kira-kira dapat dicapai, memilih alternatif terbaik dari berbagai alternatif yang tersedia, dan rencana yang dipilih karyawan untuk direalisasikan.

\section{c. Perencanaan SDM Dalam Peningkatan Mutu Pendidikan}

Perencanaan sumber daya manusia memiliki dampak yang besar bagi manajemen suatu organisasi dalam meningkatkan mutu pendidikan. Perencanaan sumber daya manusia itu sendiri akan menjadi bagian yang sangat penting dari tugas manajemen organisasi. Jika sumber daya manusia tidak dikelola dengan baik maka tujuan organisasi tidak akan tercapai. Kompleksitas pengelolaan sumber daya manusia sangat dipengaruhi oleh banyak faktor. Hal ini sesuai dengan perkembangan dan kemajuan saat ini. Sumber daya manusia yang kompeten dan berkualitas sangat dibutuhkan untuk mendukung suatu kegiatan pendidikan. Dengan manajemen sumber daya manusia yang baik, sebuah lembaga pendidikan dapat membuat kemajuan di lembaga tersebut (Siagian, 2001). Strategi yang dapat digunakan dalam manajemen sumber daya manusia adalah sebagai berikut: merekrut guru dengan membuka iklan, menempatkan "guru yang tepat pada pekerjaan yang tepat.”, mendelegasikan kekuasaan dan tanggung jawab kepada senior, guru yang kompeten dan cakap dan memberikan bimbingan kepada guru. 
Penyebab rendahnya mutu pendidikan antara lain pengelolaan pendidikan yang tidak profesional dan rendahnya kualitas sumber daya manusia dalam hal ini adalah guru. Rendahnya kualitas guru terlihat dari guru yang mengajar. Dunia pendidikan, dukungan manajemen sumber daya manusia harus kuat dan komitmen kepada pemimpin yang mutlak bagi keberhasilan organisasi secara keseluruhan (Mulyasa, 2002). Dalam rangka peningkatan mutu pendidikan yang telah dilakukan oleh Pemerintah sebagaimana tertuang dalam Peraturan Pemerintah Nomor 19 Tahun 2005 tentang Standar Nasional Pendidikan. Peraturan Pemerintah tersebut mengindikasikan adanya peningkatan tenaga kependidikan atau guru. Oleh karena itu, guru harus meningkatkan kompetensinya sesuai standar yang ditetapkan pemerintah.

\section{METODE PENELITIAN}

Penelitian ini merupakan penelitian kualitatif lapangan. Penelitian kualitatif adalah penelitian yang bertujuan untuk mengungkap suatu gejala yang menjadi objek suatu bidang ilmu. Lebih khusus lagi, tujuan penelitian adalah untuk mengungkap kebenaran atau kesimpulan tentang suatu objek yang kemudian dapat dijadikan dasar untuk membentuk suatu teori. Teori merupakan rangkuman menyeluruh dari suatu gejala (Hanurawan, 2016). Pendekatan penelitian yang digunakan dalam konteks ini adalah pendekatan deskriptif kualitatif. Pendekatan deskriptif adalah pendekatan dimana data yang dikumpulkan berupa kata-kata, gambar, dan bukan angka. Data tersebut dapat diperoleh dari wawancara, catatan lapangan, foto, video tape, dokumen, catatan atau memo dan dokumen resmi lainnya (Moleong, 1986).

Pendekatan ini dipilih karena digunakan untuk menggambarkan apa yang sedang terjadi tentang suatu situasi yang terjadi melalui penjelasan bahasa tentang maraknya kasus pembajakan buku oleh mahasiswa. Metodologi kualitatif adalah prosedur penelitian yang menghasilkan data deskriptif berupa kata-kata tertulis atau lisan dari orang-orang dan perilaku yang dapat diamati (Moleong, 1986). Demikian data yang diperoleh, baik berupa informasi, gejala, maupun pengamatan tentang "Perencanaan Sumber Daya Manusia dalam peningkatan mutu pendidikan di SMA Muhammadiyah Selong lebih tepat jika berupa kata-kata menurut pendekatan kualitatif, sehingga agar diperoleh pemahaman yang lebih dalam dan luas.Proses penelitian disajikan sesuai tahapannya, yaitu tahap pra lapangan, tahap kegiatan lapangan, dan tahap pasca lapangan.

\section{HASIL PENELITIAN DAN PEMBAHASAN}

Perencanaan SDM adalah proses dalam menentukan perpindahan guru/dosen di lembaga/instansi/lembaga dari posisi yang diinginkan di masa yang akan datang, perencanaan SDM adalah proses mengantisipasi dan membuat ketentuan atau persyaratan untuk mengatur arus pergerakan tenaga kerja ke dalam pekerja), masuk (promosi, mutasi, dan demosi) dan keluar (pensiun, berhenti, dan diberhentikan) dalam suatu organisasi atau perusahaan. Dan perencanaan SDM juga merupakan proses penetapan strategi untuk memperoleh, memanfaatkan, mengembangkan, dan memelihara SDM sesuai dengan kebutuhan organisasi/perusahaan saat ini dan perkembangannya di masa yang akan datang (Nawawi, 2015). Definisi ini menjelaskan pentingnya perencanaan SDM, karena aliran SDM harus diprediksi sejak awal. Penelitian ini bertujuan untuk mengkaji dan menemukan perencanaan SDM dalam peningkatan kualitas di SMA Muhammadiyah Selong, dan faktor-faktor yang mempengaruhi perencanaan SDM di SMA Muhammadiyah Selong serta mengkaji dan menemukan permasalahan dan kendalanya. dalam perencanaan SDM di SMA Muhammadiyah Selong dan mencari solusi dari permasalahan dan kendala tersebut. 
Hasil penelitian ini menunjukkan bahwa perencanaan SDM di SMA Muhammadiyah Selong belum berjalan efektif dan efisien. Perencanaan SDM dalam peningkatan mutu pendidikan di SMA Muhammadiyah Selong dilakukan dengan mempertimbangkan aspek-aspek terkait. Bentuk perencanaan yang dirancang berupa perencanaan sumber daya manusia, sumber daya keuangan dan sumber daya infrastruktur dan pembangunan. Perumusan rencana peningkatan mutu pendidikan di SMA Muhammadiyah Selong dilakukan melalui musyawarah dengan melibatkan seluruh komponen penting dalam suatu organisasi, antara lain: kepala sekolah, wakil kepala sekolah, guru, TU, komite sekolah.

Dalam kelanjutan musyawarah ini, prinsip partisipasi digunakan untuk memberikan saran dan gagasan positif yang dapat diterapkan dalam perencanaan peningkatan pendidikan di SMA Muhammadiyah Selong. Situasi pengambilan keputusan yang dihadapi seseorang akan mempengaruhi keberhasilan suatu keputusan yang akan diambil. Setelah seseorang berada dalam situasi pengambilan keputusan, maka dia kemudian akan mengambil tindakan oleh kepala untuk mempertimbangkan, menganalisis, memprediksi, dan membuat pilihan tentang alternatif yang ada. Sedangkan kegiatan perencanaan SDM yang dilakukan sekolah untuk meningkatkan kualitas guru atau pendidik di SMA Muhammadiyah Selong dilakukan dengan melakukan pembinaan terhadap guru, penilaian kinerja guru, penilaian pengembangan KBM, pelatihan, dan seminar. Sehubungan dengan pengembangan guru ini, kepala sekolah memandang hal ini sebagai bentuk upaya kepala sekolah kepada para guru atau pendidik untuk meningkatkan kemampuan mengajar yang bermuara pada peningkatan mutu pendidikan.

Dalam hal proses pengembangan guru yang dilakukan oleh kepala sekolah, posisi guru ditempatkan sebagai pembelajar. Oleh karena itu paradigma ini harus mampu oleh kepala sekolah menjadi beberapa prinsip pembinaan yang memungkinkan kerjasama antara kepala sekolah dan guru antara lain: ilmiah, dilakukan secara sistematis, kooperatif, kerjasama yang baik antara pembinaan dan pembinaan, pembinaan dalam rangka perbaikan, realistis, dalam sesuai dengan kondisi kebutuhan guru, progresif, pelaksanaan maju bertahap, inovatif, mendorong hal-hal baru, menciptakan rasa aman bagi guru dan memberikan kesempatan dengan pelatih dan guru. Sedangkan fungsi pembinaan ini adalah memelihara program pengajaran yang terbaik, menilai dan memperbaiki faktor-faktor yang mempengaruhi belajar dan memperbaiki situasi belajar siswa. Jadi secara ringkas pembinaan yang dilakukan kepala sekolah kepada guru berfungsi untuk menumbuhkan iklim proses dan hasil belajar melalui upaya pembinaan guru ini yang berlangsung tepat sasaran. Hal ini merupakan kreasi pembelajaran yang meningkatkan peningkatan kualitas, kesadaran dan kesadaran bahwa tugasnya sematamata untuk memberikan atau mentransformasikan pengetahuan kepada siswa, tetapi lebih dari itu kegiatan ini juga dimaksudkan sebagai upaya membina dan membentuk pendidikan siswa yang memiliki keunggulan. dalam karakter dan kebaikan. dalam hal kewajaran atau moralitas. uhammadiyah Selong dilakukan dengan meningkatkan kualitas dan kuantitas pelayanan baik secara akademik maupun teknis administrasi. Pelaksanaan program berupa kegiatan telah melaksanakan rencana yang telah disusun, bahkan dalam pelaksanaannya yaitu peningkatan mutu pendidikan dengan melaksanakan pengembangan pendidikan agama Islam berupa tahsin dan tahfidzul Qur'an, meningkat pemahaman agama melalui aliran sesat dan penguatan pendidikan agama melalui belajar mengajar dan pelaksanaan hafalan juz amma, dan hafalan shalat dan shalat dhuha berjamaah dan zikir setiap pagi. Dalam penelitian ini terdapat beberapa faktor yang mempengaruhi perencanaan SDM di SMA Muhammadiyah 
Selong yaitu tingkat pengetahuan SDM dan lingkungan yang mendukung serta dukungan dari orang tua dan siswa yang antusias mengikuti kegiatan yang dilaksanakan di sekolah. Sebagaimana dijelaskan oleh (Rivai, 2004) faktor-faktor yang mempengaruhi perencanaan SDM adalah perubahan, jumlah penduduk, perluasan angkatan kerja, angkatan kerja, dan tingkat pengetahuan yang dimiliki oleh tenaga kerja. Penelitian ini menunjukkan bahwa faktor penghambat utama dalam hal ini adalah perencanaan SDM. dalam peningkatan mutu pendidikan di SMA Muhammadiyah Selong adalah masalah kedisiplinan pendidik dan tenaga kependidikan serta fasilitas sekolah yang kurang memadai. Masalah ini sebenarnya merupakan masalah umum yang terjadi dalam dunia pendidikan di Indonesia khususnya di sektor swasta. Pembiayaan dilakukan hanya berdasarkan sumber siswa setiap bulannya. Upaya antisipatif yang dilakukan kepala sekolah dan warga sekolah lainnya adalah dengan melakukan beberapa pendekatan kepada Dinas Pendidikan Kabupaten dan Provinsi serta Dinas Pendidikan Pusat. Selain itu, meningkatkan kerjasama dengan wali siswa untuk ikut serta memecahkan masalah ini melalui pemberdayaan komite sekolah, meskipun dalam praktiknya partisipasi komite sekolah belum mendorong perubahan dan penyelesaian masalah yang dihadapi sekolah. Muhammadiyah Selong terletak pada kesadaran dan loyalitas profesional beberapa pendidik dan tenaga kependidikan yang kurang memahami tugas dan tanggung jawabnya. Terbukti ada beberapa pendidik dan tenaga kependidikan yang terlambat ke sekolah, untuk itu kepala sekolah membuat kebijakan tersendiri bagi individu dengan mengkomunikasikan keterlambatan yang terjadi kepada guru atau tenaga kependidikan yang bersangkutan agar pendidik dan tenaga kependidikan menyentuh manajemen sumber daya manusia. . Oleh karena itu, dunia pendidikan, dukungan sumber daya manusia harus kuat dan berkomitmen pada pemimpin yang merupakan keharusan mutlak bagi keberhasilan organisasi secara keseluruhan (Mulyasa, 2002). Dengan demikian, untuk meningkatkan mutu pendidikan di SMA Muhammadiyah Selong, sekolah harus melakukan analisis terhadap segala bentuk kebutuhan dan kemampuan yang berdampak pada perencanaan SDM. Serta membuat kebijakan dan membuat peraturan tentang tugas dan fungsi serta peraturan disiplin bagi pendidik dan tenaga kependidikan serta memberikan pembinaan untuk menumbuhkan rasa partisipasi dalam melaksanakan tugas dan fungsinya untuk meningkatkan mutu pendidikan di SMA Muhammadiyah Selong. Sebagaimana dijelaskan (Mulyasa, 2005) pendidikan yang berkualitas tidak hanya dilihat dari kualitas lulusan, tetapi juga mencakup bagaimana lembaga pendidikan mampu memenuhi kebutuhan pelanggan sesuai dengan standar mutu yang berlaku. Pelanggan dalam hal ini adalah pelanggan internal (tenaga kependidikan) dan pelanggan eksternal (siswa, orang tua, masyarakat, dan pengguna lulusan).

\section{PENUTUP}

Perencanaan peningkatan mutu pendidikan di SMA Muhammadiyah Selong dilakukan melalui program, langkah perencanaan, tahapan perencanaan, termasuk indikator mutu atau target yang ingin dicapai sebagai proses peningkatan mutu pendidikan. Bentuk perencanaan meliputi penataan sumber daya yang memuat pengembangan sumber daya manusia, pengembangan proses pembelajaran, serta peningkatan kapasitas sumber daya manusia untuk meningkatkan mutu pendidikan. Faktor-faktor yang mempengaruhi perencanaan SDM di SMA Muhammadiyah Selong yaitu tingkat pengetahuan SDM dan lingkungan yang mendukung serta besarnya dukungan orang tua, siswa, dan kepala sekolah terhadap eksistensi SMA Muhammadiyah Selong, peningkatan dan kualitas SDM akan memfasilitasi setiap kegiatan di SMA Muhammadiyah Selong dalam meningkatkan mutu pendidikan. Meskipun terdapat faktor penghambat perencanaan 
SDM di SMA Muhammadiyah Selong seperti fasilitas yang kurang memadai, disiplin dan kerjasama dalam melaksanakan program dan kegiatan yang telah dibuat. Namun berkat komitmen yang kuat dari kepala sekolah untuk melaksanakan perencanaan SDM, serta semangat yang tinggi dari Kepala Sekolah, siswa, dan wali Marid sehingga hingga saat ini perencanaan SDM untuk peningkatan mutu pendidikan di SMA Muhammadiyah Selong dapat masih dapat dilaksanakan dengan baik, meskipun masih perlu ditingkatkan. Solusi dari permasalahan dan kendala dalam perencanaan SDM adalah sekolah harus menganalisis segala bentuk kebutuhan dan kemampuan yang berdampak pada perencanaan SDM. Serta membuat kebijakan dan membuat peraturan tentang tugas dan fungsi serta peraturan disiplin bagi pendidik dan tenaga kependidikan serta memberikan pembinaan untuk menumbuhkan rasa partisipasi dalam melaksanakan tugas dan fungsinya untuk meningkatkan mutu pendidikan di SMA Muhammadiyah Selong.

\section{DAFTAR RUJUKAN}

Achmad, S. Ruky. 2003. Kualitas Sumber Daya Manusia. Jakarta: PT Gramedia Pustaka Utama

Agustian, Wiwin. 2009. Analisis Pengaruh Kompetensi Sumber Daya Manusia Terhadap Kinerja Karyawan Pada Universitas Bina Darma. Universitas Bina Darma. http://blog. binadarma.ac.id/ wiwinagustian/?p=37 diakses Sabtu, 2 Desember 2021 pada jam 11.27 WIB

Arikunto, Suharsimi. 2006. Prosedur Penelitian Suatu Pendekatan Praktik. Jakarta: Rineka Cipta

Atmodiwirio, Soebagio. 2000. Manajemen Pendidikan Indonesia, Jakarta:

Ardadizya JayaFattah, Nanang. 2004. Landasan Manajemen Pendidikan, (Bandung: PT. Remaja Rosdakarya).

Hanurawan, Fattah. 2010. Metode Penelitian Kualitatif Untuk Ilmu Psikologi,Jakarta: PT. Raja Grafindo Persada

Hasibuan, Malayu. 2007. Manajemen Sumber Daya Manusia, Jakarta: Bumi Aksara.

Moleong, Lexy J. 1995. Metode Penelitian Kualitatif, Bandung: Remaja Rosdakarya.

Mulyasa, E. 2005. Menjadi Kepala Sekolah Profesional dalam Mensukseskan MBS dan KBK, Bandung: PT. Remaja Rosdakarya.

Nawawi, Hadari. 2015. Perencanaan SDM untuk Organisasi Profit yangKompetitif,Yogyakarta:Gadjah Mada University Press

Pratiwi, Ami. 2010. Pengaruh Kualitas Sumber Daya Manusia Dan Motivasi Kerja Terhadap Produktivotas Kerja Karyawan Di PT Djitoe Tobacco Surakarta. Surakarta: Universitas Muhammadiyah Surakarta

Pendiknas. 2001. Manajemen Peningkatan Mutu Berbasis Sekolah,Jakarta

P. Siagan, Sondang. 2001. Manajemen Sumber Daya Manusia, Jakarta : Bumi Aksara. 
Ritawati, RA. 2015. "Perencanaan Dan Pengembangan Guru/DosenSebagai Sumber Daya Manusia (SDM)Di Lembaga Pendidikan Formal", Jurnal Istinbath, No.16 Th.XIV (Juni 2015)

Rivai, Veithzal. 2004. Manajemen Sumber daya Manusia Untuk Perusahaan, edisi 1, Jakarta, PT.Raja Grafindo Persada.Simamora, Henry. Manajemen Sumber DayaManusia,Yogyakarta:STIE YKPN 